\title{
Separation/Preconcentration of Al(III) from Water Samples via Sorptive-Flotation Technique Using Silica Nanoparticles Modified with Folic Acid
}

\author{
HANY M. YOUSSEF ${ }^{1,2 *}$ \\ ${ }^{1}$ Department of Chemistry, College of Science and Humanities in Al-Kharj, Prince Sattam bin Abdulaziz University, \\ Al-Kharj 11942, Saudi Arabia \\ ${ }^{2}$ Department of Chemistry, Faculty of Science, Mansoura University, Mansoura 35516, Egypt
}

\begin{abstract}
In the present work, silica nanoparticles functionalized with folic acid (Nano-SiO $2-\mathrm{FA}$ ) were synthesized and characterized thru elemental analysis, infrared spectroscopy (FT-IR), BrunauerEmmett-Teller (BET) surface area determination, and scanning electron microscope (SEM). Nano-SiOFA was examined as a sustainable and promising sorbent for preconcentration of Al(III) from natural water samples by sorptive-flotation $(S F)$ separation technique before its determination by flame atomic absorption spectrometry (FAAS). A several trials were made in lab, to determine the feasibility of using Nano-SiO ${ }_{2}-\mathrm{FA}$ as a sorbent and oleic acid as a surfactant. The influence of: solution $\mathrm{pH}$, temperature, shaking time, surfactant, sorbent and Al(III) concentration and the presence of foreign ions that affect the sorptive-flotation process were investigated. Good results attained under optimum circumstances, at $\mathrm{pH} 3.5$ and $\sim 25^{\circ} \mathrm{C}$, according to which nearly $100 \%$ of aluminum was separated. The procedure was successfully applied to recover aluminum spiked to some natural water samples. Moreover, a sorption and flotation mechanism is suggested.
\end{abstract}

Keywords: preconcentration, silica nanoparticles, sorptive-flotation, folic acid

\section{Introduction}

$\mathrm{Al}$ and Al-salts are being widely used in various industries such as drugs, beverages, packing materials, and dye industry [1]. Al high level in wastewaters prevents the growth of microorganisms which help organic materials stabilization in water. High levels of $\mathrm{Al}^{3+}$ ions in water are unpleasant and found to be neurotoxic [2,3]. Also, it is concerned with several diseases as Parkinson and Alzheimer's $[4,5]$, bone softening, renal failure and anaemia [6]. Al presents in soils naturally in the form of minerals as, alumino-silicates (kaolin, feldspars and micas), hydroxides and oxides [7]. Foods and water are the most important sources for $\mathrm{Al}$ exposure. Al levels in waters with neutral $\mathrm{pH}$ ranged $\left(0.001-0.05 \mathrm{mg} \cdot \mathrm{L}^{-1}\right)$ [8]. According to Environmental Protection Agency (EPA), Al in drinking water has a level of (0.05-0.2 $\left.\mathrm{mg} \cdot \mathrm{L}^{-1}\right)$ [9]. The high detection limit $\left(\mathrm{D}_{\mathrm{L}}\right)$ of flame atomic absorption spectrometry (FAAS) and presence of matrix effects make it impossible for direct analysis of these low levels of metal ions without using a preconcentration procedure. Consequently, separation/preconcentration of analytes is required [10]. Several of separation/preconcentration techniques for metal ions in trace amount including adsorption on dissimilar adsorbents, solvent extraction [11], cloud point extraction, solid-phase extraction, co-precipitation, liquid-liquid micro-extraction have been discussed [12-15]. Recently, separation/preconcentration method namely flotation has received significant attention because it's simple and rapid method, and has good separation yield more than $95 \%$ and a wide possibility of usages for recovery purpose $[16,17]$.

Nowadays, more interest focused on the using of chelating fibers for separation and removing metal ions from aqueous media. Chelating fibers have several advantages as large sorption capacity, ease of regeneration and high selectivity which may be attributed to high sorption kinetics, low cost, large surface areas and presence of active sites [18-20]. Silica one of the most commonly used sorbent in chemical analysis owing to its numerus advantages as thermal, chemical, and mechanical stability, comparing to other sorbents [21].

*email: hanyyoussef178@gmail.com,hany_moustafa@mans.edu.eg 
The silanol groups present on the silica surface is considered being weak ion exchangers and have low interaction and binding force with the target analyte [22]. Hence, certain functional groups must be immobilized on silica surface to give selectivity behavior for surface of silica. Folic acid (Fig. 1), known commercially as vitamin B9 is a water-soluble substance and exhibits versatile ligation behaviors via the carboxylate group which can act as a mono, bi or bridging ligand bind to metal ions [23-25]. Many studies have been reported on the binding between folic acid and metals such as $\mathrm{Cd}(\mathrm{II}), \mathrm{Pb}(\mathrm{II}), \mathrm{Cu}(\mathrm{II})$, $\mathrm{Zn}(\mathrm{II}), \mathrm{Fe}(\mathrm{III})$, and $\mathrm{Hg}$ (II) [24, 26]. So, folic acid is considered being a green and ecofriendly sorbent for binding with metal ions. Owing to the above facts, this work aim to surface modification of chlorinated nanosilica with folic acid to produce $\mathrm{Nano}_{-} \mathrm{SiO}_{2}-\mathrm{FA}$ nanocomposite. The produced sorbent was used for the preconcentration of $\mathrm{Al}^{3+}$ from different water samples by batch mode using sorptive-flotation (SF) technique<smiles>Nc1nc(O)c2nc(CNc3ccc(C(=O)N[C@@H](CCC(=O)O)C(=O)O)cc3)cnc2n1</smiles>

Figure 1. Structure of folic acid

\section{Materials and methods}

\subsection{Materials and reagents}

Powder of sodium silicate $\left(\mathrm{Na}_{2} \mathrm{SiO}_{3} .9 \mathrm{H}_{2} \mathrm{O}\right)$ which act as $\mathrm{Si}$ source was obtained from (SigmaAldrich, St. Louis, MO, USA), cetyltrimethylammonium bromide (CTAB) which act as structure directing agent was purchased from (Merck, Darmstadt, Germany), (3-chloropropyl)trimethoxysilane (3-CPTMS) which act as silylating agent was supplied by (Sigma-Aldrich, St. Louis, MO, USA), folic acid (97\%) [Pteroylglutamic acid, PGA] from (TITAN BIOTECH LIMITED, India). Doubly distilled water was used during all investigates. The glassware was kept overnight in $\left(10 \% \mathrm{HNO}_{3}\right)$ then, washed by doubly distilled water and air dried. $1000 \mathrm{ppm} \mathrm{Al}^{3+}$ ion was prepared by dissolving suitable quantity of $\mathrm{AlCl}_{3} .6 \mathrm{H}_{2} \mathrm{O}$ (Merck, Darmstadt, Germany) in doubly distilled water. Oleic acid (HOL), $6.36 \times 10^{-2}$ mol . $\mathrm{L}^{-1}$, was prepared by mixing $20 \mathrm{~mL}$ with $1.0 \mathrm{~L}$ kerosene. $\mathrm{HCl}$ and $\mathrm{NaOH}$ were used for adjustment of $p \mathrm{H}$.

\subsection{Apparatus}

\subsubsection{Flame atomic absorption spectrometry}

The remaining concentration of $\mathrm{Al}^{3+}$ ion in the filtrate was determined by Flame Atomic Absorption Spectrometry (FAAS) (GBC, SensAA Series) with air-acetylene flame under the optimal instrumental conditions shown in Table 1.

Table 1. Optimum instrumental conditions for $\mathrm{Al}^{3+}$ determination by FAAS:

\begin{tabular}{cc}
\hline Wave length, $\mathrm{nm}$ & 309.3 \\
Working calibrating range, $\mathrm{ppm}$ & $0.02-0.12$ \\
Sensitivity, $\mu \mathrm{g} / \mathrm{ml}$ & 0.03 \\
\hline
\end{tabular}

\subsubsection{Infrared spectra}

FT-IR spectra were performed via (Nicolet $i 10$ FT-IR, ThermoFisher Scientific, USA) spectrometer in the range of $\left(4000-400 \mathrm{~cm}^{-1}\right)$. 


\subsubsection{Scanning electron microscope}

Scanning electron microscope (SEM, Quanta FEG 250 (Field Emission Gun), ThermoFisher Scientific, USA) at an accelerating voltage of $30 \mathrm{kV}$, magnification 14xup to 1000000, was used for the assessment of surface morphology.

\subsubsection{Surface area}

The surface area investigation of prepared sorbent was carried out with nitrogen adsorption at $-196^{\circ} \mathrm{C}$ using surface area analyzer (QUANTACHROME-NOVA ${ }^{\circledR} 2000 \mathrm{e}$ series).

\subsubsection{Flotation cell}

The flotation process was occurred in a cylindrical test tube with $1.5 \mathrm{~cm}$ inner diameter and $29 \mathrm{~cm}$ length.

\subsection{Methodology}

\subsubsection{Preparation of sorbent}

\subsubsection{Synthesis of nanosized silica}

Synthesis of nanosized silica was carried out using cetyltrimethylammonium bromide (CTAB) as template, sodium silicate powder $\left(\mathrm{Na}_{2} \mathrm{SiO}_{3} .9 \mathrm{H}_{2} \mathrm{O}\right)$ as $\mathrm{Si}$ source and $\mathrm{HCl}$ as $p \mathrm{H}$ controlling agent. $12 \mathrm{~g}$ CTAB was placed in $460 \mathrm{~mL}$ of doubly distilled water, followed by stirring for $15 \mathrm{~min}$ then $80.377 \mathrm{~g}$ of $\mathrm{Na}_{2} \mathrm{SiO}_{3} .9 \mathrm{H}_{2} \mathrm{O}$ was added to the mixture followed by stirring for $30 \mathrm{~min}$. Concentrated $\mathrm{HCl}$ added to the mixture for $p \mathrm{H}$ adjustment at 9. The stirring non-stop for 4 . The resulting bulky white gelatinous precipitate was transferred to a vessel of Teflon and left for $24 \mathrm{~h}$ at $25^{\circ} \mathrm{C}$. After that, the final product was filtered and washed with doubly distilled water after that dried at $50^{\circ} \mathrm{C}$ for $6 \mathrm{~h}$ finally, the sample was calcined at $550^{\circ} \mathrm{C}$ for $6 \mathrm{~h}$ [27].

\subsubsection{Immobilization of silylating reagent}

$2.0 \mathrm{~g}$ of prepared nano- $\mathrm{SiO}_{2}$ were mixed with $50 \mathrm{~mL}$ of dry toluene in a $250 \mathrm{~mL}$ flask. Then, $4.0 \mathrm{~mL}$ of (3-chloropropyl)trimethoxysilane was added and the product refluxed at $110^{\circ} \mathrm{C}$ with non-stop stirring for $6 \mathrm{hrs}$. The final product of nano- $\mathrm{SiO}_{2}-\mathrm{Cl}$ separated and washed by diethylether and ethanol many times then dried at $50^{\circ} \mathrm{C}$.

\subsubsection{Functionalization of chlorinated nanosilica with folic acid}

$2.0 \mathrm{~g}$ of prepared nano- $\mathrm{SiO}_{2}-\mathrm{Cl}$ was added to $50 \mathrm{~mL}$ of dry toluene in a $250 \mathrm{~mL}$ flask, then $2.0 \mathrm{~g}$ of folic acid was added and the mixture refluxed at $110^{\circ} \mathrm{C}$ and non-stop stirring for $6 \mathrm{hrs}$. The final product of nano- $\mathrm{SiO}_{2}-\mathrm{FA}$ separated by filtration and washed by diethylether and ethanol many times and finally dried at $50^{\circ} \mathrm{C}$.

\subsubsection{Batch method for metal ion uptake via sorptive-flotation (SF) technique}

$10 \mathrm{~mL}$ aqueous solution containing defined amounts of $\mathrm{Al}^{3+}$ ion, sorbent and $\left(\mathrm{HNO}_{3}\right.$ or $\mathrm{NaOH}$ for $p \mathrm{H}$-controlling) was placed in a flotation tube followed by shaking for the optimum time, after that 3 $\mathrm{mL}$ of HOL (with optimum concentration) was added, finally the tube was inverted 20 times upside down by hand then kept 5 min standing for complete flotation.

The removal $\%$ of $\mathrm{Al}^{3+}$ ions calculated as following:

$$
\operatorname{Re} \%=\left[\left(\mathrm{C}_{\mathrm{i}}-\mathrm{C}_{\mathrm{r}}\right) / \mathrm{C}_{\mathrm{i}}\right] \times \mathbf{1 0 0}
$$

where, $\mathrm{C}_{\mathrm{r}}$ and $\mathrm{C}_{\mathrm{i}}$ indicated the residual and initial $\mathrm{Al}^{3+}$ concentrations, respectively. 


\subsubsection{Effect of foreign ions}

To study the applicability of the proposed procedure, the effect of interfering ions which could interfere with $\mathrm{Al}^{3+}$ ions removal using $\mathrm{Nano}_{-} \mathrm{SiO}_{2}-\mathrm{FA}$ was tested under the optimum conditions.

\subsubsection{Desorption study}

To test sorbent desorption, $25 \mathrm{mg}$ Nano- $\mathrm{SiO}_{2}-\mathrm{FA}$ was added to $25 \mathrm{~mL}$ solution containing $10 \mathrm{ppm}$ $\mathrm{Al}^{3+}$ at $p \mathrm{H} 3.5$ and $25^{\circ} \mathrm{C}$ and shacked for $30 \mathrm{~min}$. The sorbent was filtered and washed with doubly distilled water, to remove the unloaded $\mathrm{Al}^{3+}$. Then, $5 \mathrm{~mL}$ of $\mathrm{HNO}_{3}$ of different concentrations was added to Nano-SiO $2-\mathrm{FA}-\mathrm{Al}^{3+}$ complex followed by shaking for 15 min finally, mixture was filtrated and $\mathrm{Al}^{3+}$ concentration was measured in the filtrate. The desorption ratio (D\%) was determined by equation (2):

$$
\mathrm{D} \%=\left[\mathrm{Cd}_{\mathrm{d}} /\left(\mathrm{C}_{\mathrm{o}}-\mathrm{Ce}_{\mathrm{e}}\right) \mathrm{V}\right] \times \mathbf{1 0 0}
$$

where $\mathrm{C}_{\mathrm{d}}$ is the concentration of $\mathrm{Al}^{3+}$ in desorption solution (ppm); $\mathrm{V}_{\mathrm{d}}$ is the volume of the desorption solution (L); and $\mathrm{V}$ is the volume of solution (L), $\mathrm{C}_{\mathrm{o}}(\mathrm{ppm})$ and $\mathrm{C}_{\mathrm{e}}(\mathrm{ppm})$ initial and equilibrated $\mathrm{Al}^{3+}$ ion concentrations, respectively.

\subsubsection{Analytical application}

Natural water samples were collected from different locations in Egypt (Mansoura, Gamasa, Ras ElBarr, El-Manzalah and Alexandria), at a depth of $50 \mathrm{~cm}$ from the upper level, then all these samples were filtered then total dissolved salts (TDS) and $p \mathrm{H}$ were determined and finally all samples acidified with $\mathrm{HNO}_{3}$ and preserved in a dark polyethylene bottle in a refrigerator at $5^{\circ} \mathrm{C}$ for future use. The applicability of Nano-SiO $2-\mathrm{FA}$ for uptake of the $\mathrm{Al}^{3+}$ ion from different natural water samples was studied for spiked concentration. The investigates were performed using $25 \mathrm{~mL}$ of filtered sample at $p \mathrm{H}$ 3.5 containing $25 \mathrm{mg}$ sorbent and $1 \times 10^{-3} \mathrm{~mol} / \mathrm{L} \mathrm{HOL}$, finally the mixture shacked for $30 \mathrm{~min}$. The removal \% was determined by equation (1).

\section{Results and discussions}

\subsection{Sorbent characterization}

\subsubsection{Elemental analysis $(\mathrm{C}, \mathrm{H}$ and $\mathrm{N})$}

The obtained results from elemental analysis of $\mathrm{Nano}_{-} \mathrm{SiO}_{2}-\mathrm{FA}$ sorbent have been shown in Table 2 . It's obvious that, after the chlorination step and modification of chlorinated nanosilica, the presence of nitrogen content considered as a good indication for insertion of the folic acid moieties onto the chlorinated nanosilica.

Table 2. Elemental analysis $(\mathrm{C}, \mathrm{H}$ and $\mathrm{N})$ for prepared sorbent:

\begin{tabular}{ccc}
\hline$\% \mathrm{C}$ & $\% \mathrm{H}$ & $\% \mathrm{~N}$ \\
26.66 & 3.39 & 10.16 \\
\hline
\end{tabular}

\subsubsection{FT-IR analysis}

The FT-IR spectra of different steps for prepared sorbent are illustrated in Figure 2. Before calcination, FT-IR spectrum exhibited bands at $3422 \mathrm{~cm}^{-1}\left(\mathrm{O}-\mathrm{H}\right.$ stretching from $\mathrm{H}_{2} \mathrm{O}$ and $\left.\mathrm{Si}-\mathrm{OH}\right)$, $2926 / 2855 \mathrm{~cm}^{-1}$ (C-H stretching of CTAB), $1650 \mathrm{~cm}^{-1}$ (Si-OH and $\mathrm{H}-\mathrm{OH}$ bending for Si-OH and $\mathrm{H}_{2} \mathrm{O}$ ), $1481 \mathrm{~cm}^{-1}\left(\mathrm{CH}_{2}\right.$ bending of CTAB), 1226/1068 $\mathrm{cm}^{-1}$ (asymmetric Si-O-Si stretching), $962 \mathrm{~cm}^{-1}$ (Si-O stretching of Si-OH), $795 \mathrm{~cm}^{-1}$ (symmetric stretching of Si-O-Si), $455 \mathrm{~cm}^{-1}$ (Si-O-Si bending) [28]. After calcination and functionalization, bands due to CTAB is absent from spectra and 3 distinctive peaks at 454, 845 and $1084 \mathrm{~cm}^{-1}$ are present which refer to Si-O-Si stretching, Si-O stretching and Si-O bending vibrations, respectively. Nano-SiO $2-\mathrm{FA}$ was found to give many other peaks at 3530, 3419, 2967, 1695, $1608,1485,1412$ and $1340 \mathrm{~cm}^{-1}$ that are assigned for $\mathrm{N}-\mathrm{H}$ stretching, O-H stretching, C-H stretching, $\mathrm{C}=\mathrm{O}$ stretching, $\mathrm{C}=\mathrm{N}$ stretching, $\mathrm{C}=\mathrm{C}$ stretching, $\mathrm{C}-\mathrm{C}$ bending and $\mathrm{C}-\mathrm{N}$ stretching vibrations, 
respectively. The obtained results of FT-IR confirmed the successful surface loading of $\mathrm{Nano}^{-\mathrm{SiO}_{2}}$ with folic acid to form Nano-SiO 2 -FA [29-31].

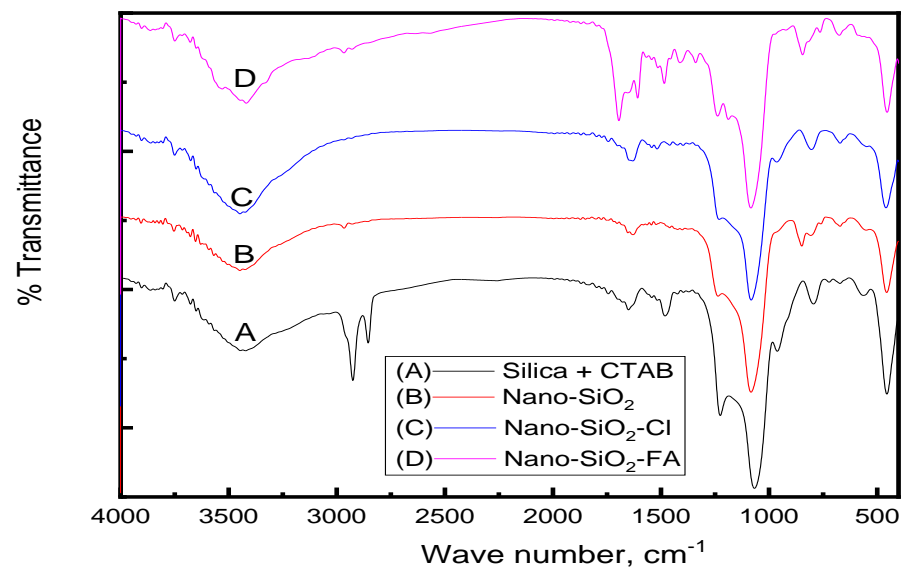

Figure 2. IR spectra of prepared nanosized silica and different modified forms

\subsubsection{Scanning electron microscope}

SEM was used to evaluate surface morphology and existence of $\mathrm{Nano}_{-} \mathrm{SiO}_{2}-\mathrm{FA}$ nanocomposite in the form of nanoparticles. Figures ( $3 \mathrm{a}, 3 \mathrm{~b}$ ) represent the $\mathrm{SEM}$ graphs for Nano-SiO${ }_{2}$ and $\mathrm{Nano}-\mathrm{SiO}_{2}-\mathrm{FA}$, respectively. From Figures $(3 \mathrm{a}, 3 \mathrm{~b})$ it was notice that, the $\mathrm{Nano}-\mathrm{SiO}_{2}$ is consists of homogenous, uniform and almost spherical nanoparticles. But the immobilized FA on Nano-SiO 2 surface was found to be in aggregate forms, which refers to the covering of sorbent surface with folic acid.

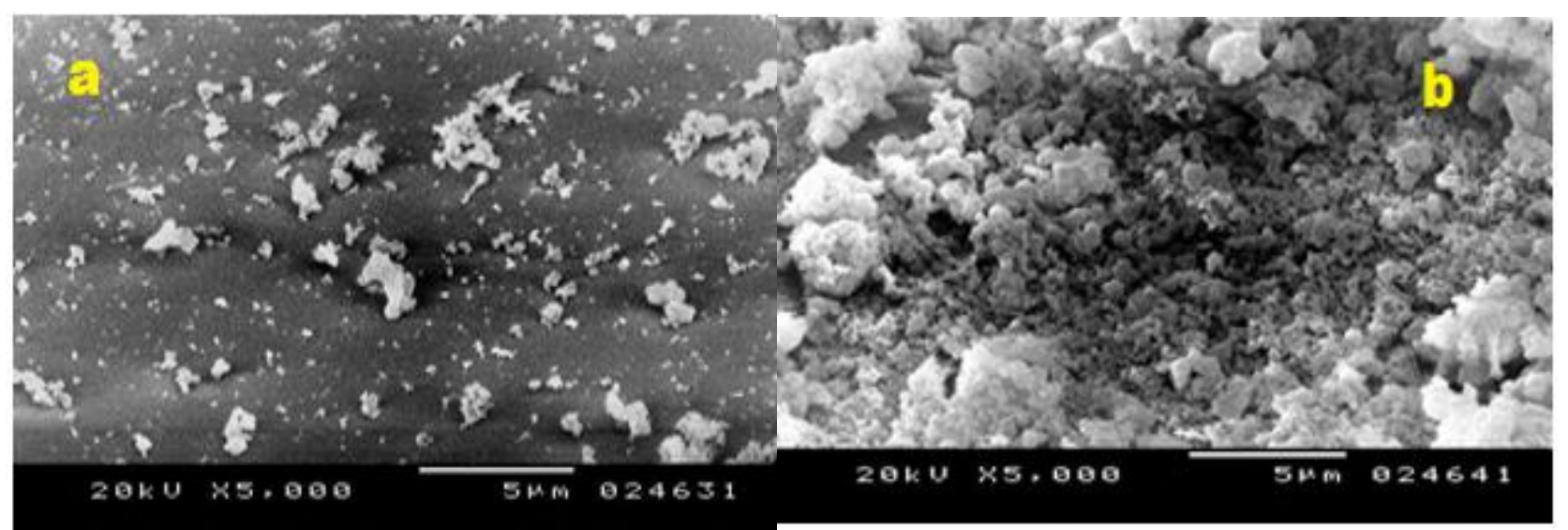

Figure 3. SEM images of (a) $\mathrm{Nano}_{-} \mathrm{SiO}_{2}$, (b) $\mathrm{Nano}_{-} \mathrm{SiO}_{2}-\mathrm{FA}$

\subsubsection{Surface area}

The surface area found to be $455.438 \mathrm{~m}^{2} / \mathrm{g}$.

\subsection{Batch process using sorptive-flotation (SF)}

\subsubsection{Influence of $p \mathbf{H}$}

The removal $\%$ of $\mathrm{Al}^{3+}$ ions over $p \mathrm{H}$ range (2-6) was studied to get optimum $p \mathrm{H}$. Figure 4 shows the

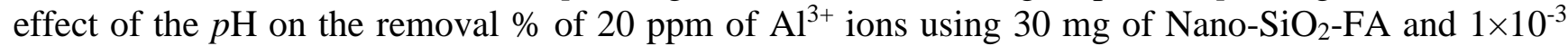
mol. $\mathrm{L}^{-1}$ of HOL. At $p \mathrm{H}<3$, functional groups of $\mathrm{Nano}^{-} \mathrm{SiO}_{2}-\mathrm{FA}$ are protonated with $\mathrm{H}_{3} \mathrm{O}^{+}$ions and the overall surface charge on the sorbent becomes positive. Thus, at $p \mathrm{H}$ below 3 , the removal efficiency of $\mathrm{Al}^{3+}$ is low which can be attributed to the competition between $\mathrm{Al}^{3+}$ ions and protons for the active sites of sorbent surface. At $p \mathrm{H}$ range (3-6), there are lower competition between $\mathrm{H}_{3} \mathrm{O}^{+}$and $\mathrm{Al}^{3+}$ ions for the 
active sites of sorbent surface therefore more sites are easily available for metal ion binding, so the removal $\%$ of metal ions is increased and the optimal $p \mathrm{H}$ value found to be 3.5 .

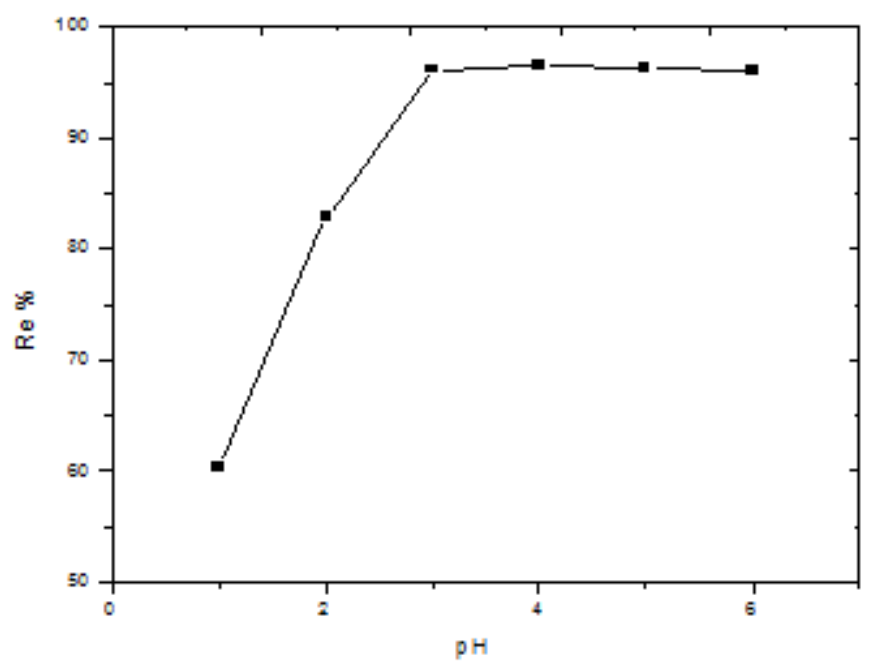

Figure 4. Effect of $p \mathrm{H}$ on the flotation of the $\mathrm{Al}^{3+}$ [Experimental conditions: $10 \mathrm{~mL}$ aqueous solution containing: $20 \mathrm{ppm} \mathrm{Al}^{3+}$ ion, $30 \mathrm{mg}$ of $\mathrm{Nano}_{-} \mathrm{SiO}_{2}-\mathrm{FA}$, $[\mathrm{HOL}]=1 \times 10^{-3} \mathrm{~mol} . \mathrm{L}^{-1}$, at $5 \mathrm{~min}$ shaking time and $\left.25^{\circ} \mathrm{C}\right]$

\subsubsection{Influence of sorbent and sorbate concentrations}

Two runs of trials were done to test the influence of $\mathrm{Nano}_{-} \mathrm{SiO}_{2}-\mathrm{FA}$ dosage (Figure 5) and $\mathrm{Al}^{3+}$ concentration (Figure 6) on the removal \% of $\mathrm{Al}^{3+}$ ions from aqueous medium at $p \mathrm{H} 3.5$ using $1 \times 10^{-3}$ mol.L $\mathrm{L}^{-1}$ of HOL. Figure 5 shows that, the removal $\%$ of $\mathrm{Al}^{3+}$ improved with raising $\mathrm{Nano}^{3} \mathrm{SiO}_{2}-\mathrm{FA}$ dose, while it reduced with increasing $\mathrm{Al}^{3+}$ concentration (Figure 6). Achieving the maximum separation of $\mathrm{Al}^{3+}$ ions at a higher Nano-SiO $2-\mathrm{FA}$ dose may be owing to increasing number of active sites present on the sorbent surface and available to $\mathrm{Al}^{3+}$. Therefore, $30 \mathrm{mg}$ of $\mathrm{Nano}-\mathrm{SiO}_{2}-\mathrm{FA}$ can be appropriate amount for the removal of $\mathrm{Al}^{3+}$ with a concentration $\leq 20 \mathrm{ppm}$.

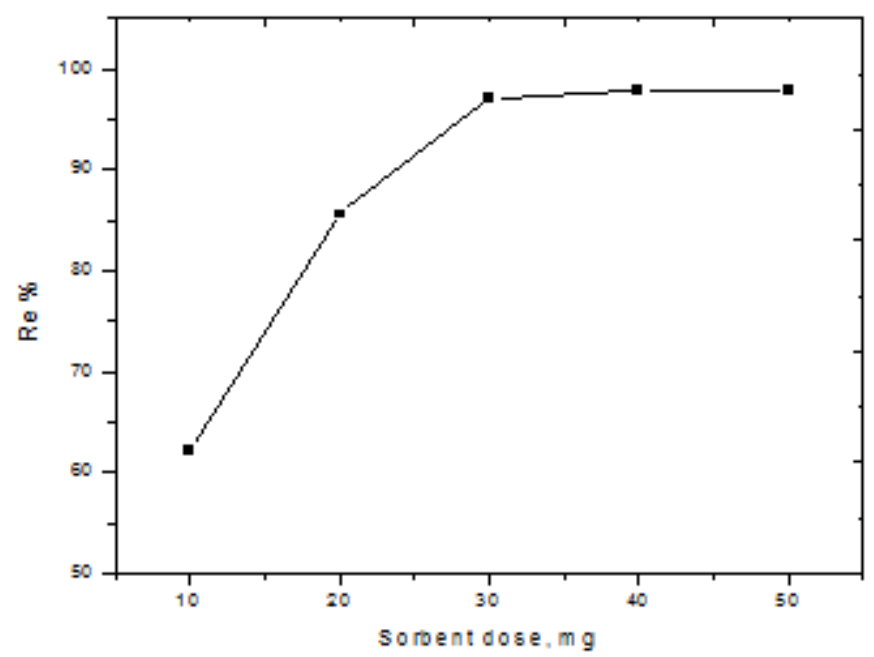

Figure 5. Effect of sorbent dose on the flotation of the $\mathrm{Al}^{3+}$ [Experimental conditions: $10 \mathrm{~mL}$ aqueous solution containing: $20 \mathrm{ppm} \mathrm{Al} \mathrm{A}^{3+}$ ion, $[\mathrm{HOL}]=1 \times 10^{-3} \mathrm{~mol} . \mathrm{L}^{-1}$, at $p \mathrm{H} 3.5,5$ min shaking time and $\left.25^{\circ} \mathrm{C}\right]$ 


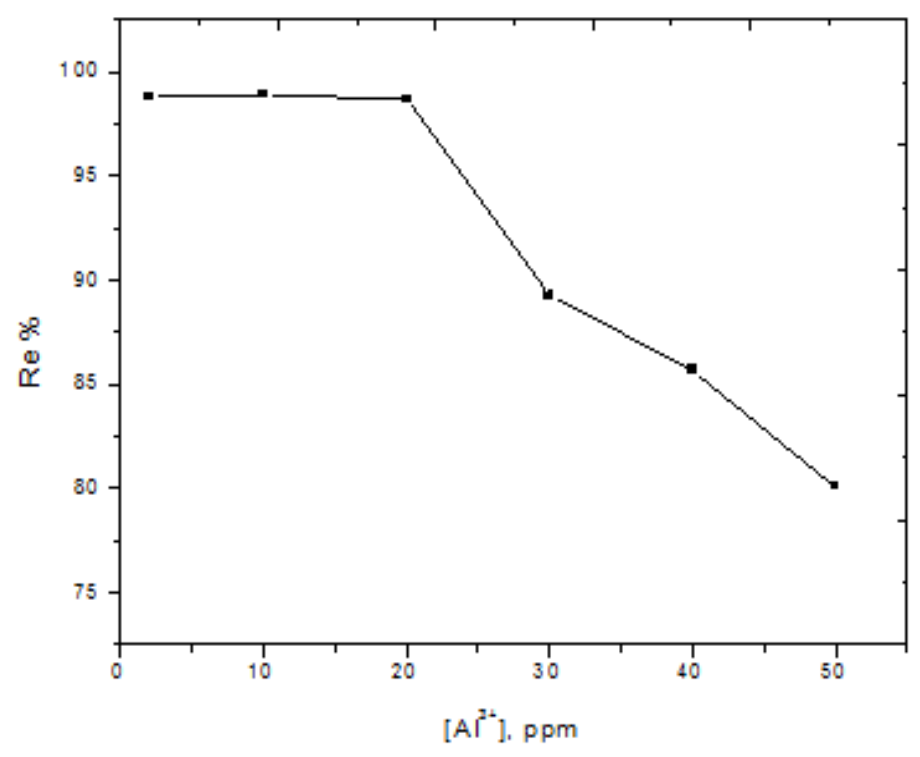

Figure 6. Effect metal ion concentration on the flotation of the $\mathrm{Al}^{3+}$ [Experimental conditions: $10 \mathrm{~mL}$ aqueous solution containing:

$30 \mathrm{mg}$ of $\mathrm{Nano}-\mathrm{SiO}_{2}-\mathrm{FA},[\mathrm{HOL}]=1 \times 10^{-3} \mathrm{~mol} . \mathrm{L}^{-1}$, at $p \mathrm{H} 3.5,5$ min shaking time and $\left.25^{\circ} \mathrm{C}\right]$

\subsubsection{Influence of surfactant concentration}

A run of trials were performed to remove $20 \mathrm{ppm}$ of $\mathrm{Al}^{3+}{ }^{3+}$ ions from aqueous solutions at $p \mathrm{H} \mathrm{3.5,} \mathrm{using}$

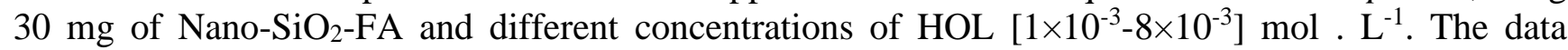
obtained in Figure 7 confirmed that, a quantitative separation of $\mathrm{Al}^{3+}$ ions was achieved at $\mathrm{HOL}$ concentration of $\left(1 \times 10^{-3}-4 \times 10^{-3} \mathrm{~mol} . \mathrm{L}^{-1}\right)$. The removal of $\mathrm{Al}^{3+}$ ions reduced at higher concentrations, a phenomenon that can be attributed to the formation of a stable hydrated envelop of surfactant on the surface of air bubble, or due to the formation of hydrated micellar layer on the sorbent surface. In both cases, the hydrophobicity of the sorbent surface decrease the flotation efficiency $[32,33]$.

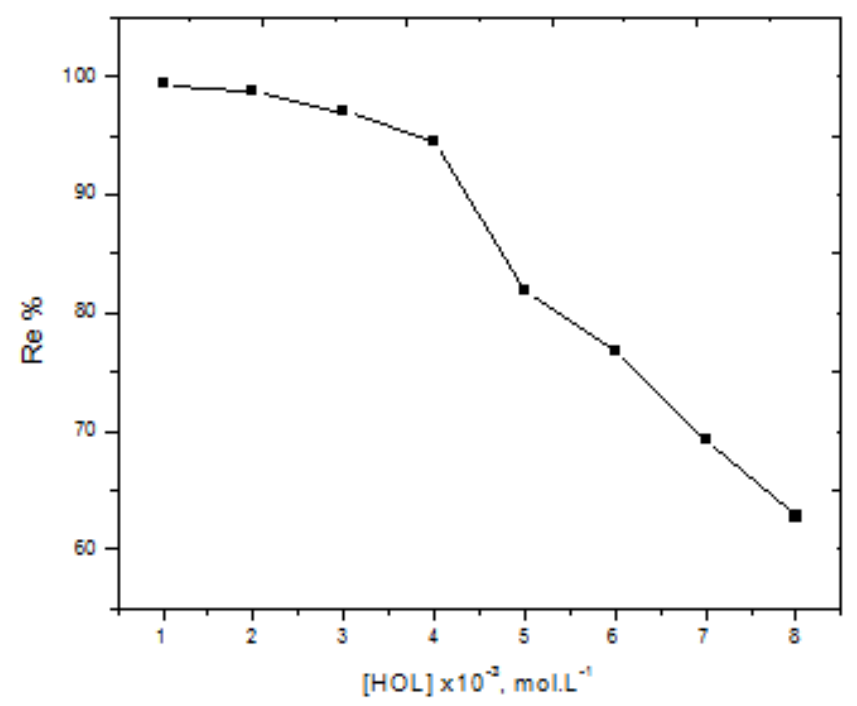

Figure 7. Effect of surfactant concentration on the flotation of the $\mathrm{Al}^{3+}$ [Experimental conditions: $10 \mathrm{~mL}$ aqueous solution containing: $20 \mathrm{ppm} \mathrm{Al}{ }^{3+}$ ion, $30 \mathrm{mg}$ of $\mathrm{Nano}_{-} \mathrm{SiO}_{2}-\mathrm{FA}$, at $p \mathrm{H} \mathrm{3.5,5}$ min shaking time and $\left.25^{\circ} \mathrm{C}\right]$ 


\subsubsection{Influence of shaking time}

The effect of shaking time was also examined utilizing $20 \mathrm{ppm}$ of $\mathrm{Al}^{3+}$ ions, $30 \mathrm{mg}$ of $\mathrm{Nano}_{-} \mathrm{SiO}_{2-}$ FA and $1 \times 10^{-3} \mathrm{M}$ of HOL at $p \mathrm{H} 3.5$. The range of shaking time was (1-10) min. The attained results in Figure 8 exposed that, the removing \% enhanced to its maximum value after shaking time of 5 min. Subsequently, 5 min of shaking was believed to be sufficiently for the quantitative removal of $\mathrm{Al}^{3+}$ ions.

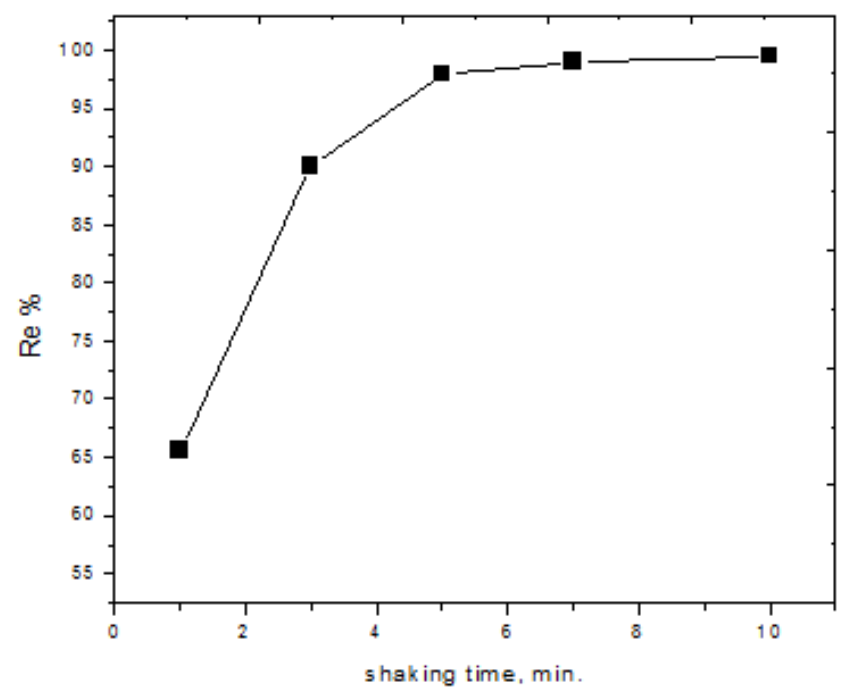

Figure 8. Effect of shaking time on the flotation of the $\mathrm{Al}^{3+}$ [Experimental conditions: $10 \mathrm{~mL}$ aqueous solution containing:

$20 \mathrm{ppm} \mathrm{Al}^{3+}$ ion, $30 \mathrm{mg}$ of $\mathrm{Nano}-\mathrm{SiO}_{2}-\mathrm{FA}$, $[\mathrm{HOL}]=1 \times 10^{-3} \mathrm{~mol} . \mathrm{L}^{-1}$, at $p \mathrm{H} 3.5$ and $\left.25^{\circ} \mathrm{C}\right]$

\subsubsection{Influence of temperature}

For such study, one solution containing $20 \mathrm{ppm}$ of $\mathrm{Al}^{3+}$ ions and $30 \mathrm{mg}$ of $\mathrm{Nano}_{-} \mathrm{SiO}_{2}-\mathrm{FA}$ and a second solution containing $1 \times 10^{-3} \mathrm{~mol} . \mathrm{L}^{-1}$ of HOL were heated up or cooled to the same temperature utilizing a water bath. Surfactant was rapidly poured onto the $\mathrm{Al}^{3+}$ solution, after which the mixture was floated. The found results in Figure 9 confirmed that, the removal $\%$ of $\mathrm{Al}^{3+}$ ions decreased with temperature increasing.

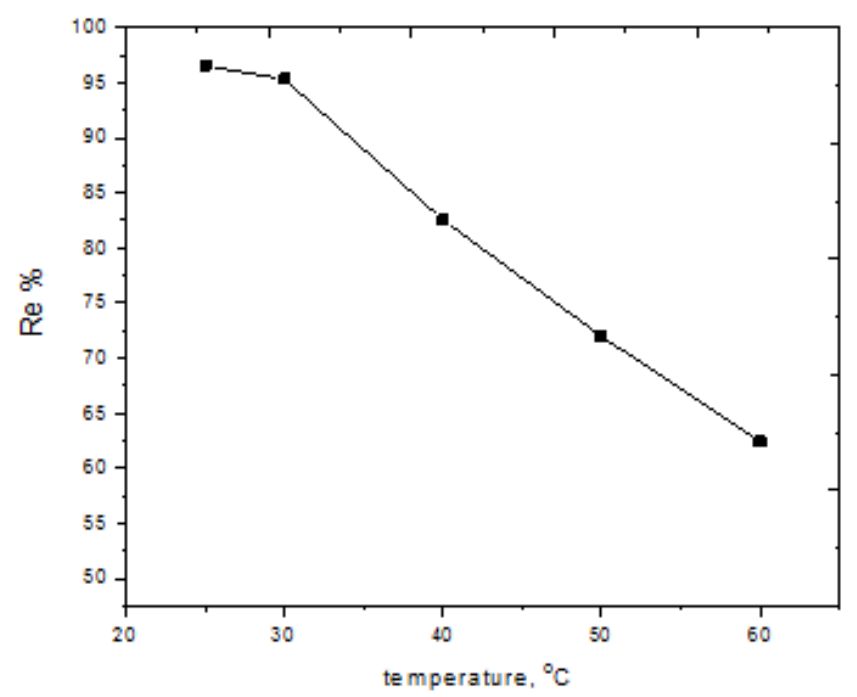

Figure 9. Effect of temperature on the flotation of the $\mathrm{Al}^{3+}$

[Experimental conditions: $10 \mathrm{~mL}$ aqueous solution containing: $20 \mathrm{ppm} \mathrm{Al}{ }^{3+}$ ion, $30 \mathrm{mg}$ of Nano-SiO${ }_{2}-\mathrm{FA}$, $[\mathrm{HOL}]=1 \times 10^{-3} \mathrm{~mol} . \mathrm{L}^{-1}$, at $p \mathrm{H} 3.5$ and 5 min shaking time] 


\subsection{Effect of foreign ions}

To check the selectivity of the suggested methods and in order to investigate the relevance of Nano$\mathrm{SiO}_{2}$-FA for separation of $\mathrm{Al}^{3+}$ ions, the interference of several foreign ions on the removal of $\mathrm{Al}^{3+}$ ions was examined with pre-optimized experimental procedures. All cations were used as chlorides salt while the anions were applied as sodium salts. The data showed maximum tolerable concentration of foreign ions, with relative error $\leq 5 \%$. The results attained in Table 3 indicated that, all the studied foreign ions with relatively high concentrations (compared to that of $\mathrm{Al}^{3+}$ ions) have no adverse effect on the analysis of $\mathrm{Al}^{3+}$ by the mentioned techniques. Although $\mathrm{Mg}^{2+}$ and $\mathrm{Ca}^{2+}$ ions may form magnesium and calcium oleats, the expected harmful effect on the recovery of $\mathrm{Al}^{3+}$ ions was not observed. Consequently, the suggested sorptive-flotation procedure could find its own applications for the recovery of $\mathrm{Al}^{3+}$ ions from different water matrices.

Table 3. Effects of foreign ions (in binary mixtures) on recovery of $\mathrm{Al}^{3+}$ :

\begin{tabular}{|c|c|c|c|c|}
\hline \multicolumn{2}{|c|}{ Interfering ions } & Added salt & $\begin{array}{l}\text { Tolerable limit } \\
\left(\mu g \mathrm{~mL}^{-1}\right)\end{array}$ & $\operatorname{Re} \%$ \\
\hline \multirow[t]{8}{*}{ Anions } & $\mathrm{CH}_{3} \mathrm{COO}^{-}$ & $\mathrm{CH}_{3} \mathrm{COONa}$ & 180 & 95.5 \\
\hline & $\mathrm{Cl}^{-}$ & $\mathrm{NaCl}$ & 1000 & 99.0 \\
\hline & $\mathrm{NO}_{3}=$ & $\mathrm{NaNO}_{3}$ & $900^{-1}$ & 97.8 \\
\hline & $\mathrm{HCO}_{3}^{--}$ & $\mathrm{NaHCO}_{3}$ & $1000^{-}$ & 979 \\
\hline & $\mathrm{C}_{2} \mathrm{O}_{4}{ }^{2--}$ & $\mathrm{Na}_{2} \mathrm{C}_{2} \mathrm{O}_{4}$ & 190 & 95.4 \\
\hline & $\mathrm{SO}_{4}^{2-}$ & $\mathrm{Na}_{2} \mathrm{SO}_{4}$ & 800 & 97.1 \\
\hline & $\mathrm{PO}_{4}^{3---}$ & $\mathrm{Na}_{3} \mathrm{PO}_{4}$ & $150^{-}$ & 97.3 \\
\hline & $\mathrm{C}_{6} \mathrm{H}_{5} \mathrm{O}_{7}^{3-}$ & $\mathrm{Na}_{3} \mathrm{C}_{6} \mathrm{H}_{5} \mathrm{O}_{7}$ & 190 & 97.0 \\
\hline \multirow[t]{12}{*}{ Cations } & $\mathrm{NH}_{4}^{+}$ & $\mathrm{NH}_{4} \mathrm{Cl}$ & 250 & 98.9 \\
\hline & $\mathrm{K}^{+-}$ & $\mathrm{KCl}$ & 1000 & 979 \\
\hline & $\mathrm{Na}^{+-}$ & $\mathrm{NaCl}$ & 1000 & 99.3 \\
\hline & $\mathrm{Mg}^{\mathrm{S}^{+}}$ & $\mathrm{MgCl}_{2}$ & 100 & 97.8 \\
\hline & $\mathrm{Ca}^{2+}$ & $\mathrm{CaCl}_{2}$ & 100 & 96.0 \\
\hline & $\mathrm{Ba}^{2+^{-}}$ & $\mathrm{BaCl}_{2}$ & $120^{-}$ & 96.4 \\
\hline & $\mathrm{Cd}^{1+}$ & $\mathrm{C}^{-} \mathrm{Cl}_{2}$ & $100^{-}$ & 95.7 \\
\hline & $\mathrm{Cu}^{2+}$ & $\mathrm{CuCl}_{2}$ & 100 & 96.2 \\
\hline & $\mathrm{Hg}^{\mathrm{S}^{-}}$ & $\mathrm{HgCl}_{2}$ & 100 & 98.0 \\
\hline & $\mathrm{Fe}^{2+^{--}}$ & $\mathrm{FeCl}_{2}$ & 100 & 97.1 \\
\hline & $\mathrm{Zn}^{2+}$ & $\mathrm{ZnSO}_{4}$ & 90 & 97.7 \\
\hline & $\mathrm{Ni}^{2+}$ & $\mathrm{NiSO}_{4}$ & 50 & 98.3 \\
\hline
\end{tabular}

Experimental conditions: $10 \mathrm{~mL}$ aqueous solution containing: $20 \mathrm{ppm} \mathrm{Al}^{3+}, 30 \mathrm{mg}$ of $\mathrm{Nano}_{-} \mathrm{SiO}_{2}-\mathrm{FA}$, at $p \mathrm{H} 3.5$ using $1 \times 10^{-3}$ mol. $\mathrm{L}^{-1}$ of $\mathrm{HOL}$, shaking time $5 \mathrm{~min}$ and $25^{\circ} \mathrm{C}$.

\subsection{Desorption study}

Desorption tests contribute to regenerate the sorbent, also to recover $\mathrm{Al}^{3+}$ ions from the used sorbent moreover protecting the environment from solid waste disposal difficulties. Tries were made to desorb $\mathrm{Al}^{3+}$ ions from the metal laden sorbent using different concentrations of $\mathrm{HNO}_{3}$. The effect of $\mathrm{HNO}_{3}$ concentration $(0.1,0.5,1.0$ and $1.5 \mathrm{M})$ on the elution yield was assessed and the results offered in Table 4 display that quantitative extraction was achieved at concentrations of $1.5 \mathrm{M}$ of nitric acid and quantitative yield (>96\%) was obtained when $5 \mathrm{~mL}$ of $1.5 \mathrm{M} \mathrm{HNO}_{3}$ was taken.

Table 4. Desorption study of $\mathrm{Al}^{3+}$ by $\mathrm{HNO}_{3}$ :

\begin{tabular}{ll}
\hline$\left[\mathrm{HNO}_{3}\right], \mathrm{mol}_{\mathrm{L}}^{-1}$ & Desorption \% \\
\hline 0.1 & 52.61 \\
0.5 & 63.37 \\
1.0 & 85.12 \\
1.5 & 96.87 \\
\hline
\end{tabular}

\subsection{Analytical applications}

To examine the application of flotation procedures, a run of trials were conducted to recover spiked concentration of $\mathrm{Al}^{3+}$ ions added to some natural water samples. The results present in Table 5 show that 
the recovery was quantitative and satisfactory $(\sim 100 \%)$ with a relative standard deviation (RSD) does not exceed $1.15 \%$.

Table 5. Recovery of $20 \mathrm{ppm}$ of $\mathrm{Al}$ (III) ions added to some water samples:

\begin{tabular}{llll}
\hline Sample type & Sample location & $\mathrm{Al}^{3+}$ found, $\mathrm{ppm}$ & Uptake \% \\
\hline Tap water & Mansoura city & 19.992 & 99.96 \\
Nile water & Mansoura city & 19.936 & 99.68 \\
Lake water & El-Manzalah & 19.678 & 98.39 \\
Sea water & Ras El-Barr & 19.868 & 99.34 \\
& Gamasa & 19.958 & 99.79 \\
& Alexandria & 19.974 & 99.87 \\
Underground water & Mansoura city & 19.952 & 99.76 \\
\hline
\end{tabular}

\subsection{Suggested mechanism for sorptive-flotation process:}

Prior to talk about the probable mechanism, the following points should be taken into account:

1. Utmost metal ions are separated by: (i) adsorption onto sorbent surface by co-precipitation as $\mathrm{M}(\mathrm{OH})_{(\mathrm{s})}$; (ii) flocculation by adsorption of hydrolytic forms or (iii) complexation with surface functional groups $[34,35]$.

2. Aluminum species may present as: $\mathrm{Al}(\mathrm{OH})^{2+}, \mathrm{Al}(\mathrm{OH})_{2}{ }^{+}$and $\mathrm{Al}(\mathrm{OH})_{4}{ }^{-} \mathrm{Al}(\mathrm{OH})_{3}{ }^{0}\left(\mathrm{Al}_{\mathrm{n}}(\mathrm{OH})_{\mathrm{m}}{ }^{(3 \mathrm{n}-}\right.$ $\left.{ }^{\mathrm{m})+}\right), \mathrm{Al}(\mathrm{OH})_{3}(\mathrm{~s})$ according to the $p \mathrm{H}$ of the medium [36].

3. The presence of $\mathrm{N}-\mathrm{H}, \mathrm{C}=\mathrm{O}$ and $\mathrm{O}-\mathrm{H}$ groups on sorbent surface was confirmed by the characteristic bands at 3530,3419 and $1695 \mathrm{~cm}^{-1}$, respectively.

4. Oleic acid begins to dissociate at $p \mathrm{H} \geq 5.2$ [37].

Consequently, the proposed mechanism for sorptive-flotation can be as follows:

1. At $p \mathrm{H}<3$, the charge on sorbent surface becomes positive due to protonation with $\mathrm{H}_{3} \mathrm{O}^{+}$ions. Thus, at $p \mathrm{H}$ below 3 , the removal efficiency of $\mathrm{Al}^{3+}$ is owing to the adsorption of hydrolytic species of aluminum on sorbent surface.

2. In the $p \mathrm{H}$ range $3-6$, where the maximal removal of $\mathrm{Al}^{3+}$ ions occurred, adsorption may be electrostatically in nature and taking place via co-precipitation of the colloidal positive precipitates of aluminum.

3. Then, the adsorbent-adsorbate system is made hydrophobic by combination with un-dissociated surfactant molecules through $\mathrm{H}$-bonds and/or chemically with oleate anions, then the resultant aggregates are floated to solution surface with the support of air bubbles.

4. In alkaline medium, the removal of $\mathrm{Al}^{3+}$ ions decreases which may be attributed to the inability of adsorption of the negative species, $\mathrm{Al}(\mathrm{OH})_{4}{ }^{-}$, or negative oleate ions on the negative surface of sorbent [38].

\section{Conclusions}

Preparation and using of nanosilica functionalized with folic acid in clean technology has discussed in the present work. Nano- $\mathrm{SiO}_{2}-\mathrm{FA}$ was successfully prepared thru loading of folic acid on the surface of chlorinated nanosilica $\left(\mathrm{Nano}_{-} \mathrm{SiO}_{2}-\mathrm{Cl}\right)$ and its structure was proved by several assessments. Nano$\mathrm{SiO}_{2}$-FA was used as an effective sorbent for selective separation and preconcentration of $\mathrm{Al}^{3+}$ ions from natural water samples using sorptive-flotation separation method before its determination by flame atomic absorption spectrometry (FAAS). The experimental data showed that the $\mathrm{Al}^{3+}$ removal by Nano$\mathrm{SiO}_{2}-\mathrm{FA}$ was dependant on $p \mathrm{H}$. Also, it was indicated that the prepared sorbent can be regenerated easily using $\mathrm{HNO}_{3}$ as eluent. Finally, the separation method was applied to the preconcentration of $\mathrm{Al}^{3+}$ ions from real samples without matrix interference.

Acknowledgement: This publication was supported by the Deanship of Scientific Research at Prince Sattam bin Abdulaziz University, Alkharj, Saudi Arabia. 


\section{References}

1. G. SPOSITO, The environmental chemistry of aluminum, CRC Press, 1995.

2. L. KOCHIAN, O. HOEKENGA, M. PINEROS, How do crop plants tolerate acid soils: Mechanisms of aluminum tolerance and phosphorous efficiency Annu. Rev, Plant Physiol. Plant Mol. Biol, 46 (1995) 237-260.

3. T.P. FLATEN, A.C. ALFREY, J.D. BIRCHALL, J. SAVORY, R.A. YOKEL, Status and future concerns of clinical and environmental aluminum toxicology, Journal of Toxicology and Environmental Health Part A, 48 (1996) 527-542.

4. A. CAMPBELL, The potential role of aluminium in Alzheimer's disease, Nephrology Dialysis Transplantation, 17 (2002) 17-20.

5. R.A. YOKEL, The toxicology of aluminum in the brain: a review, Neurotoxicology, 21 (2000) 813 828.

6. D. KREWSKI, R.A. YOKEL, E. NIEBOER, D. BORCHELT, J. COHEN, J. HARRY, S. KACEW, J. LINDSAY, A.M. MAHFOUZ, V. RONDEAU, Human health risk assessment for aluminium, aluminium oxide, and aluminium hydroxide, Journal of Toxicology and Environmental Health, Part B, 10 (2007) 1-269.

7.B.-S. NEGREANU-PIRJOL, T. NEGREANU-PIRJOL, R. SIRBU, D.R. POPOVICIU, Bioaccumulation and Effects of Aluminium on Plant Growth in Three Culture Plants Species, Rev. Chim., 70(2), 2019, 602-604.

8. A. WHO, W.H. Organization, International Programme on Chemical Safety, Geneva, Environmental Health Criteria, 194 (1997).

9.*** U. EPA, Environmental Protection Agency, Secondary Drinking Water, Guidance for Nuisance Chemicals (2000), in.

10.I. NARIN, M. TUZEN, M. SOYLAK, Aluminium determination in environmental samples by graphite furnace atomic absorption spectrometry after solid phase extraction on Amberlite XAD1180/pyrocatechol violet chelating resin, Talanta, 63 (2004) 411-418.

11. I.C. POPESCU, L. STOICA, C. CONSTANTIN, A.M. STANESCU, Equilibrium and Kinetics of $\mathrm{U}(\mathrm{VI})_{(\mathrm{aq})}$ Adsorption on in situ Generated $\mathrm{Fe}_{2} \mathrm{O}_{3} \cdot \mathrm{nH}_{2} \mathrm{O}$, Rev. Chim., 70(10), 2019, 3482-3485.

12. S. BAYTAK, A.R. TÜRKER, Determination of chromium, cadmium and manganese in water and fish samples after preconcentration using Penicillium digitatum immobilized on pumice stone, CleanSoil, air, water, 37 (2009) 314-318.

13.A. BAYSAL, M. KAHRAMAN, S. AKMAN, The solid phase extraction of lead using silver nanoparticles-attached to silica gel prior to its determination by FAAS, Current Analytical Chemistry, 5 (2009) 352-357.

14.H. CIFTCI, Solid phase extraction method for the determination of cobalt in water samples on duolite XAD-761 resin using 4-(2-Pyridylazo) resorcinol by FAAS, Current Analytical Chemistry, 6 (2010) 154-160.

15. M. REZAEE, Y. YAMINI, A. KHANCHI, M. FARAJI, A. SALEH, A simple and rapid new dispersive liquid-liquid microextraction based on solidification of floating organic drop combined with inductively coupled plasma-optical emission spectrometry for preconcentration and determination of aluminium in water samples, Journal of hazardous materials, 178 (2010) 766-770.

16. L. STOICA, M. DINCULESCU, C.G. PLAPCIANU, Mn (II) recovery from aqueous systems by flotation, Water Research, 32 (1998) 3021-3030.

17.S.E.-S. GHAZY, S.E.-S. SAMRA, A.E.-F.M. MAHDY, S.M. EL-MORSY, Flotation-separation of aluminum from some water samples using powdered marble waste and oleic acid, Analytical sciences, 19 (2003) 1401-1406.

18.S. DENG, R. BAI, J. CHEN, Behaviors and mechanisms of copper adsorption on hydrolyzed polyacrylonitrile fibers, Journal of colloid and interface science, 260 (2003) 265-272.

19.S. DENG, R. BAI, Removal of trivalent and hexavalent chromium with aminated polyacrylonitrile fibers: performance and mechanisms, Water research, 38 (2004) 2424-2432. 
20. M. YIĞITOĞLU, M. ARSLAN, Selective removal of $\mathrm{Cr}$ (VI) ions from aqueous solutions including $\mathrm{Cr}$ (VI), Cu (II) and Cd (II) ions by 4-vinly pyridine/2-hydroxyethylmethacrylate monomer mixture grafted poly (ethylene terephthalate) fiber, Journal of hazardous materials, 166 (2009) 435-444.

21. D.L. KAPLAN, Introduction to biopolymers from renewable resources, in: Biopolymers from renewable resources, Springer, 1998, pp. 1-29.

22. F. OKIEIMEN, C. SOGBAIKE, J. EBHOAYE, Removal of cadmium and copper ions from aqueous solution with cellulose graft copolymers, Separation and purification Technology, 44 (2005) 85-89.

23. R.C. MEHROTRA, A. SINGH, Recent trends in metal alkoxide chemistry, Progress in Inorganic Chemistry, 46 (1997) 239-454.

24. M.A. EL-WAHED, M. REFAT, S. EL-MEGHARBEL, Synthesis, spectroscopic and thermal characterization of some transition metal complexes of folic acid, Spectrochimica Acta Part A: Molecular and Biomolecular Spectroscopy, 70 (2008) 916-922.

25.N. NOMBONA, W. CHIDAWANYIKA, T. NYOKONG, Photophysical behaviour of asymmetrically substituted metal free, $\mathrm{Mg}$ and $\mathrm{Zn}$ phthalocyanines in the presence of folic acid, Polyhedron, 30 (2011) 654-659.

26. E. HAMED, M. ATTIA, K. BASSIOUNY, Synthesis, spectroscopic and thermal characterization of copper (II) and iron (III) complexes of folic acid and their absorption efficiency in the blood, Bioinorganic chemistry and applications, 2009 (2009).

27.F. HAVASI, A. GHORBANI-CHOGHAMARANI, F. NIKPOUR, Pd-Grafted functionalized mesoporous MCM-41: A novel, green and heterogeneous nanocatalyst for the selective synthesis of phenols and anilines from aryl halides in water, New Journal of Chemistry, 39 (2015) 6504-6512.

28.C. HUO, J. OUYANG, H. YANG, CuO nanoparticles encapsulated inside Al-MCM-41 mesoporous materials via direct synthetic route, Scientific reports, 4 (2014) 3682.

29. T.M. ABDEL-FATTAH, M.E. MAHMOUD, Selective extraction of toxic heavy metal oxyanions and cations by a novel silica gel phase functionalized by vitamin B4, Chemical engineering journal, 172 (2011) 177-183.

30. Y. CAI, C. LI, D. WU, W. WANG, F. TAN, X. WANG, P.K. WONG, X. QIAO, HIGHLY active $\mathrm{MgO}$ nanoparticles for simultaneous bacterial inactivation and heavy metal removal from aqueous solution, Chemical Engineering Journal, 312 (2017) 158-166.

31. Z. PENG, C. XIONG, W. WANG, F. TAN, Y. XU, X. WANG, X. QIAO, Facile modification of nanoscale zero-valent iron with high stability for $\mathrm{Cr}(\mathrm{VI})$ remediation, Science of the Total Environment, 596 (2017) 266-273.

32.V.I. KLASSEN, V.A. MOKROUSOV, An introduction to the theory of flotation, Butterworths, 1963. 33. S. GHAZY, S. SAMRA, S. EL-MORSY, Removal of copper (II) from aqueous solutions by flotation using limestone fines as the sorbent and oleic acid as the surfactant, Adsorption Science \& Technology, 19 (2001) 175-185.

34. R. APAK, E. TÜTEM, M. HÜGÜL, J. HIZAL, Heavy metal cation retention by unconventional sorbents (red muds and fly ashes), Water research, 32 (1998) 430-440.

35. A. ZOUBOULIS, K. KYDROS, K. MATIS, flotation of metal-loaded clay Anion Exchangers, water res, 29 (1995) 1755.

36. P.G. CAMPBELL, M. BISSON, R. BOUGIE, A. TESSIER, J.P. VILLENEUVE, Speciation of aluminum in acidic freshwaters, Analytical Chemistry, 55 (1983) 2246-2252.

37. S. GHAZY, S. SAMRA, S. EL-MORSY, Sorptive-Flotation of Copper (II) from Water Using Different Types of Powdered Activated Carbons as Sorbents and Oleic Acid as Surfactant, Adsorption Science \& Technology, 19 (2001) 721-736.

38. A. ZOUBOULIS, N. LAZARIDIS, D. ZAMBOULIS, Powdered activated carbon separation from water by foam flotation, Separation science and technology, 29 (1994) 385-400.

Manuscript received: 11.03 .2020 